\title{
ART. 22(4) BRUSSELS I REGULATION AND ITS SUCCESSOR ONLY APPLY TO CASES CONCERNED WITH THE ACTUAL REGISTRATION OR VALIDITY OF THE LISTED IP RIGHTS. COMMENTARY ON THE JUDGMENT OF THE COURT OF JUSTICE OF THE EUROPEAN UNION OF 5 OCTOBER 2017, C-341/16*
}

\author{
ARTÍCULO 22.4 DEL REGLAMENTO BRUSELAS I \\ Y SU SUCESOR SOLO SE APLICAN A LOS CASOS \\ RELACIONADOS CON EL REGISTRO EFECTIVO \\ O LA VALIDEZ DE LOS DERECHOS DE PROPIEDAD \\ INTELECTUAL ENUMERADOS. COMENTARIO DE LA \\ SENTENCIA DEL TRIBUNAL DE JUSTICIA DE LA UNIÓN \\ EUROPEA DE 5 DE OCTUBRE DE 2017, C-341/16
}

\author{
KILIAN SENDLMEIER \\ Doctoral candidate and research assistant \\ Institute for Private International and Comparative Law \\ University of Cologne, Germany
}

Recibido: 15.01.2019 / Aceptado: 28.01.2019

DOI: https://doi.org/10.20318/cdt.2019.4668

\begin{abstract}
The CJEU reaffirms its established case law on Art. 22(4) Brussels I Regulation (No. 44/2001) and interprets the provision narrowly. Courts in member states in which patents, trade marks, designs, or similar rights that are required to be deposited or registered, have jurisdiction only in cases that are actually concerned with the registration or validity of these IP rights. A case concerned with the potential ownership of such rights falls within the general provision of Art. 2(1) Brussels I and, therefore, is to be brought before courts in the member state where the defendant is domiciled.

Keywords: judicial cooperation in civil and commercial matters, Brussels I Regulation (No. 44/2001), Jurisdiction under Art. 2(1) and Art. 22(4) Brussels I Regulation, jurisdiction in proceedings concerned with IP rights, registration of property of a trade mark $^{* *}$

Resumen: El Tribunal de Justicia de la Unión Europea mantiene su jurisprudencia establecida sobre el Art. 22.4 del Reglamento (CE) no 44/2001 de Bruselas I e interpreta este artículo en sentido estricto. Los tribunales de los Estados miembros en los que se exige el depósito o el registro de patentes, marcas, dibujos y modelos u otros derechos similares solo son competentes en los casos en que se trata realmente del registro o la validez de estos derechos de propiedad intelectual. Un caso relativo a

"For the court's reasoning, see Court of Justice of the European Union 5 October 2017 - C-341/16, Praxis des Internationalen Privat- und Verfahrensrechts (IPRax), 2018, pp. 405-407.

${ }^{* *}$ Most keywords taken from the original judgement of the Court (Second Chamber) 5 October 2017, C-341/16, ECLI:EU: C:2017:738.
\end{abstract}


la posible titularidad de ese derecho entra en el ámbito de la disposición general del Art. 2.1 del Reglamento Bruselas I y, por lo tanto, debe ser llevado ante los tribunales de aquel estado miembro en el que el demandado esté domiciliado.

Palabras clave: procedimiento prejudicial, cooperación judicial en materia civil y mercantil, Reglamento (CE) $n^{\circ}$ 44/2001, competencia judicial, Artículo 2, apartado 1, competencia de los órganos jurisdiccionales del domicilio del demandado, Artículo 22, punto 4, competencia exclusiva en materia detítulos de propiedad intelectual, inscripción como titular de una marca.

Summary: I. Introduction. II. Facts of the Case. III. The court's decision. 1. German law and its consequences for the application of Art. 22(4) Brussels I Regulation. 2. Applicability of the Brussels I Regulation. 3. Jurisdiction under Article 2(1) and Article 22(4) Brussels I. 4. Narrow interpretation of Art. 22(4) Brussels I. 5. Continuity in the interpretation and uniformity of legal concepts: Duijnstee and Hanssen. 6. No effect of other EU intellectual property legislation. IV. Commentary. 1. Wording of Art. 22(4) Brussels I. 2. Criticism of the fundament of Duijnstee. 3. Consideration of Art. 24(3) Brussels I Recast. V. Conclusions.

\section{Introduction}

1. For jurisdiction in intellectual property proceedings within the EU, Art. 24(4) Brussels I (recast) Regulation ${ }^{1}$ is arguably one of the most relevant provisions these days. Its predecessors, Art. 16(4) Brussels Convention ${ }^{2}$ and Art. 22(4) Brussels I Regulation ${ }^{3}$ have been at the center of various decisions by the CJEU. ${ }^{4}$ While the scope of these provisions has been at issue many times, the CJEU's decisions have always pointed into one direction. With the decision in Hanssen ./. Prast-Knipping, this established case law receives further support, as the decision strengthens the narrow interpretation of these provisions.

2. Once again, the court emphasized that a clear line has to be drawn between issues arising from the relationship between the opposing parties, which are part of the merits of a case, and the preliminary question of the right forum to decide these questions. In its decision, rendered on 5 October 2017, the CJEU held that the question of ownership of IP rights is not covered by Art. 22(4) of the Brussels I Regulation. The same will apply for Art. 24(4) of the recast Regulation, which is worded identically.

\section{Facts of the Case}

3. A Dutch company (Hanssen Beleggingen BV) and a German heiress (Mrs. Tanja Prast-Knipping) disagreed on the ownership of a trade mark registered under number 361604 at the Benelux Intellectual Property Office ('BIPO'). The Dutch company argued that because of a number of assignments the trade mark in question was not part of the estate of Mrs. Prast-Knipping's husband at the time of his death. Therefore, Mrs. Prast-Knipping was not the owner of that trade mark and, consequently, she was unjustifiably registered as such. Hanssen Beleggingen BV sought to order Mrs. Prast-Knipping under German law to waive the registration of her name as owner of the trade mark in question.

\footnotetext{
${ }^{1}$ Regulation (EU) No. 1215/2012 of the European Parliament and of the Council of 12 December 2012 on jurisdiction and the recognition and enforcement of judgments in civil and commercial matters (recast).

21968 Brussels Convention on jurisdiction and the enforcement of judgments in civil and commercial matters (72/454/ EEC), European Law Gazette, L 299/32 of 31 December 1972, pp. 32-45.

${ }^{3}$ Council Regulation (EC) No. 44/2001 of 22 December 2000 on jurisdiction and the recognition and enforcement of judgments in civil and commercial matters.

${ }^{4}$ E.g. ECJ, 15 November 1983, Duijnstee, C-288/82, ECLI:EU:C:1983:326; ECJ, 13 July 2016, GAT, C-4/03, ECLI:EU:C:2006:457; CJEU, 14 July 2016, Brite Strike Technologies, C-230/15, ECLI:EU:C:2016:560; CJEU, 12 July 2012, Solvay, C-616/10, ECLI:EU:C:2012:445; concerning the almost identical Art. 24(4) Brussels I recast Regulation see CJEU, 16 November 2016, Schmidt, C-417/15, ECLI:EU:C:2016:881.
} 
4. Whilst the Regional Court of Düsseldorf, Germany (Landgericht Düsseldorf) saw no grounds for Hanssen's claim concerning the merits of the case, the Higher Regional Court of Düsseldorf, Germany (Oberlandesgericht Düsseldorf) as court of appeal already questioned the jurisdiction of German courts under the Brussels I Regulation. The latter Court therefore referred the case to the CJEU for a preliminary ruling. It asked the European Court to clarify the interpretation and scope of Art. 22(4) of the Brussels I Regulation:

'Does the notion of proceedings which are "concerned with the registration or validity of ... trade marks", within the meaning of Article 22(4) of Regulation [No. 44/2001], also cover a claim, brought against the formal proprietor of a Benelux trade mark registered in the Benelux trade mark register, which seeks an order requiring that defendant to make a declaration to [BIPO] that she has no entitlement to the contested mark and that she waives registration as the proprietor of that mark?' ${ }^{5}$

\section{The Court's decision}

5. The CJEU had to analyze whether the claim to waive the registration as proprietor of a trade mark and connected questions such as clarification of ownership of such rights were legal issues governed by Art. 22(4) Brussels I or if the general rule of Art. 2(1) Brussels I was the appropriate rule instead to determine jurisdiction in such cases.

\section{German law and its consequences for the application of Art. 22(4) Brussels I Regulation}

6. Under Section 812 of the German Civil Code (Bürgerliches Gesetzbuch ${ }^{6}$ ), a person who obtains something at another person's expense without legal grounds is under a duty to make restitution to this other person. The lack of legal grounds in this case might result from the circumstance that Mr. Helmut Knipping did not own the patent in question at the time of his death. Thus, Mrs. Tanja Prast-Knipping might have been unjustifiably enriched when she was registered as proprietor of the trade mark number 361604 in 2003, proximately eight years after her husband's death. Such unjust enrichment would be the legal grounds for a claim to waive respondent's registration as proprietor. Accordingly, the merits of the present case were concerned with the ownership of a specific trade mark registered at the BIPO.

7. However, no unjust enrichment could have been found if Mr. Helmut Knipping was the owner of the trademark in question at the time of his death. In this constellation, questions of ownership could be seen as preliminary to the questions of correct registration and validity of such a right. This is due to the fact that factual ownership differing from the formally registered status as proprietor might lead to a valid claim to waive such false registration. As such, Art. 22(4) Brussels I could be seen as covering cases where the claimant seeks the waiver of a registration of the defendant as proprietor as well. Nonetheless, the CJEU decided differently relying on the following reasoning.

\section{Applicability of the Brussels I Regulation (No. 44/2001)}

8. The Brussels I Regulation (No. 44/2001) was in force from 1 March 2002 until 9 January 2015, when it was replaced by the recast Brussels I Regulation (No. 1215/2012). ${ }^{7}$ In the case discussed here, the original claim was brought before the Regional Court of Düsseldorf, Germany (Landgericht Düsseldorf) on 8 June 2012 and thus during a period in which Regulation No. 44/2001 was still in for-

\footnotetext{
${ }^{5}$ CJEU, 5 October 2017, Hanssen, C-341/16, ECLI:EU:C:2017:738, para. 28.

${ }^{6}$ Bürgerliches Gesetzbuch (BGB), German Civil Code in the version promulgated on 2 January 2002, Federal Law Gazette (Bundesgesetzblatt, BGBl.) 2002 I p. 42, 2909; 2003 I p. 738, last amended by Articles 1 and 4d of the Act of 18 December 2018, BGB1. 2018 I p. 2648, 2651, English translation provided by the Langenscheidt Translation Service, available at http:// www.gesetze-im-internet.de/englisch_bgb/ (last access 7 January 2019).

7 See also M. TaXhet in F. Albrecht et al. (eds.), Beck'scher Online-Kommentar Markenrecht, $15^{\text {th }}$ ed., München, C.H. Beck, 2018, § 30 MarkenG, para. 177.
} 
ce. As stated in Art. 66(1) of the recast Brussels I Regulation all legal proceedings instituted before 10 January 2015 shall still be governed by the preceding regulations. Therefore, the CJEU had to apply the Brussels I Regulation and consider jurisdiction under its articles.

\section{Jurisdiction under Article 2(1) and Article 22(4) Brussels I}

9. According to the general rule of Art. 2(1) Brussels I, any person against whom a claim is brought before a court has to be sued at the place of his or her domicile. However, for cases concerned with IP rights as listed in Art. 22(4) Brussels I Regulation, this article gives jurisdiction to the courts of the member state in which the registration or deposit of such rights "has been applied for, has taken place or is [...] deemed to have taken place." Thus, Art. 22(4) Brussels I Regulation is lex specialis for such cases as the wording of Art. 22(4) Brussels I Regulation makes clear. ${ }^{8}$

\section{Narrow interpretation of Art. 22(4) Brussels I}

10. The CJEU strengthens its established case law on Art. 22(4) Brussels I by following the path of its earlier decisions in Duijnstee (1983) and GAT (2006).

11. According to the Court, Art. 22(4) Brussels I has to be interpreted narrowly. Thus, it does not include proceedings concerned with the waiver of a registration of trade marks where such claims are based on the allegation of the formal proprietor's missing ownership..$^{9}$ Following the general rule of Art. 2(1), Brussels I the courts at the defendant's domicile have jurisdiction for these proceedings. Only proceedings concerned with the registration or validity of such rights lie within the scope of Art. 22(4) Brussels I and are therefore governed by the jurisdiction of the courts of the member state in which the deposit or registration has been applied for, has taken place or is deemed to have taken place. ${ }^{10}$

12. This conclusion is mainly drawn from the wording ${ }^{11}$ of Art. 22(4), from the need of continuity in the interpretation of the provisions and the goal of uniformity of legal concepts in all member states $^{12}$ as well as from the provision's underlying objective. ${ }^{13}$

13. The wording of Art. 22(4) Brussels I 'proceedings concerned with the registration or validity of [...] trade marks' only mentions registration and validity express verbis. The court therefore draws the conclusion that other issues, especially issues of substantive law such as questions of ownership, are not to be decided by the courts of the member state in which the trade mark in question is registered. ${ }^{14}$ The court applies the general rule of narrow interpretation ${ }^{15}$ at this point because by giving exclusive jurisdiction to a court, the article deprives parties from their choice of forum. ${ }^{16}$

14. Next, this case note will discuss the provision's underlying objective as stated by the Court. The CJEU argues that the Regulation gives jurisdiction in Art. 22(4) to the courts of the member state in which the IP right's registration or deposition has taken place or was applied for, because these courts have a closer connection to the issue. However, the provision does not assume a closer connection and therefore

\footnotetext{
${ }^{8}$ Art. 22 Brussels I Regulation expressly creates exceptions to Art. 2(1) Brussels I Regulation: "The following courts shall have exclusive jurisdiction, regardless of domicile: [...]".

${ }^{9}$ CJEU, 5 October 2017, Hanssen, C-341/16, ECLI:EU:C:2017:738, para. 39.

${ }^{10}$ CJEU, 5 October 2017, Hanssen, C-341/16, ECLI:EU:C:2017:738, paras. 34-39.

${ }^{11}$ CJEU, 5 October 2017, Hanssen, C-341/16, ECLI:EU:C:2017:738, para. 37.

${ }^{12}$ CJEU, 5 October 2017, Hanssen, C-341/16, ECLI:EU:C:2017:738, paras. 30, 31.

${ }_{13}$ CJEU, 5 October 2017, Hanssen, C-341/16, ECLI:EU:C:2017:738, para. 37.

${ }^{14}$ CJEU, 5 October 2017, Hanssen, C-341/16, ECLI:EU:C:2017:738, para. 35.

${ }^{15}$ L. De Lima Pinheiro in U. Magnus/P. Mankowski (eds.), European Commentaries on Private International Law, Volume I Brussels Ibis Regulation, $1^{\text {st }}$ ed., Köln, Otto Schmidt, 2016, Art. 24 Brussels Ibis Regulation, para. 14; H. LinKE/W. HAU, Internationales Zivilverfahrensrecht, $7^{\text {th }}$ ed., Köln, Otto Schmidt, 2018, para. 4.12; see also P. KINDLER, „Der europäische Deliktsgerichtsstand und die gewerblichen Schutzrechte“, Gewerblicher Rechtsschutz und Urheberrecht (GRUR) 2018, pp. 1107, 1113.

${ }^{16}$ CJEU, 5 October 2017, Hanssen, C-341/16, ECLI:EU:C:2017:738, para. 32.
} 
greater competence of these courts when questions of ownership or other substantive questions concerning the relevant IP right are at stake. ${ }^{17}$ So the underlying objective of Art. 22(4) is one of closest connection and assumed greater competence. Nonetheless, a closer connection might exist in certain cases although normally courts at the defendant's domicile will solve questions of ownership most satisfactorily and efficiently. ${ }^{18}$

\section{Continuity in the interpretation and uniformity of legal concepts: Duijnstee and Hanssen}

15. The continuity with Duijnstee is pointed out by the CJEU in the Hanssen case of $2017 .{ }^{19}$ The Higher Regional Court of Düsseldorf, Germany (Oberlandesgericht Düsseldorf) cites Duijnstee as indicia $^{20}$ and the CJEU is concerned with Duijnstee's effect on Hanssen at several points. ${ }^{21}$ For the CJEU, it is important to establish a continuous interpretation of the relevant provisions ${ }^{22}$ and thereby support 'uniform application [of the same concept] in all contracting states' ${ }^{23}$.

16. In 1983, the ECJ had to decide on the case Duijnstee ./. Goderbauer, which was similar to the Hanssen case of 2017. In Duijnstee the ECJ had decided that ownership of a patent was not an issue which fell under Art. 16(4) of the Brussels Convention as antecedent of Art. 22(4) Brussels I Regulation. ${ }^{24}$ The case was also concerned with the legal relationship between the two parties (Mr. Goderbauer and an insolvent company called BV Schroefboutenfabriek) which determined the ownership of the patent in question. ${ }^{25}$ As early as in 1983, the Court ruled that questions deriving from this relationship as questions of substantive law are not covered by Art. 16(4) of the Brussels Convention. The new Hanssen decision is therefore seen as the logical extension of the case law of the CJEU. ${ }^{26}$

\section{No effect of other EU intellectual property legislation}

17. As the Court finally points out, other EU legislation such as Art. 18 of Regulation No. 207/2009 (of 26 February 2009) or Paragraph 4.6 of the BCIP (Benelux Convention on Intellectual Property of 2007) does not affect the court's findings. ${ }^{27}$ Art. 18 of Regulation No. 207/2009 specifically deals with the relationship of an agent or representative and the owner of a trade mark and, therefore, has no effect on the more general rule of Art. 22(4) Brussels I Regulation (44/2001).

18. Paragraph 4.6 of the BCIP does not play a role in the present case either, since Hanssen did not base his claim on any provision of the BCIP nor was this convention anyhow connected to the issues of the case as the CJEU points out..$^{28}$

\section{Commentary}

\section{Wording of Art. 22(4) Brussels I}

19. Despite the CJEU's decision to the contrary, the wording of Art. 22(4) Brussels I 'proceedings concerned with the registration or validity of [...] trade marks' might be seen as rather wide. As

\footnotetext{
${ }^{17}$ CJEU, 5 October 2017, Hanssen, C-341/16, ECLI:EU:C:2017:738, para. 37; see also KINDLER, GRUR 2018, pp. 1107, 1114.

${ }^{18}$ CJEU, 5 October 2017, Hanssen, C-341/16, ECLI:EU:C:2017:738, para. 33.

${ }^{19}$ CJEU, 5 October 2017, Hanssen, C-341/16, ECLI:EU:C:2017:738, para. 30.

${ }^{20}$ Düsseldorf Higher Regional Court 14 June 2016 - 20 U 104 /15, GRUR-RR 2016, p. 379, para. 8; see also CJEU, 5 October 2017, Hanssen, C-341/16, ECLI:EU:C:2017:738, para. 25.

${ }^{21}$ CJEU, 5 October 2017, Hanssen, C-341/16, ECLI:EU:C:2017:738, paras. 31, 34, 35.

${ }^{22}$ CJEU, 5 October 2017, Hanssen, C-341/16, ECLI:EU:C:2017:738, para. 30.

${ }^{23}$ CJEU, 5 October 2017, Hanssen, C-341/16, ECLI:EU:C:2017:738, para. 31.

${ }^{24}$ ECJ, 15 November 1983, Duijnstee, C-288/82, ECLI:EU:C:1983:326, para. 26.

${ }^{25}$ ECJ, 15 November 1983, Duijnstee, C-288/82, ECLI:EU:C:1983:326, para. 26.

${ }^{26}$ KINDLER, GRUR 2018, pp. 1107, 1113.

${ }^{27}$ CJEU, 5 October 2017, Hanssen, C-341/16, ECLI:EU:C:2017:738, paras. 41, 42.

${ }^{28}$ CJEU, 5 October 2017, Hanssen, C-341/16, ECLI:EU:C:2017:738, para. 42.
} 
already mentioned above (under Paragraph 7), the wording also covers preliminary questions as to the validity of a trade mark's registration. If ownership was a preliminary question, it could be covered by Art. 22(4) Brussels I Regulation.

20. At least Art. 22(4) Brussels I Regulation does not explicitly exclude this possibility. Nonetheless, ownership has to be seen as a substantial issue deriving from the legal relationship between the parties. ${ }^{29}$ Ownership is therefore not a relevant aspect to determine the right forum. Keeping the general rule in mind that exclusive jurisdiction should only be available in very specific cases, ${ }^{30}$ the Court's reasoning is convincing and scholars tend to agree. ${ }^{31}$

\section{Criticism of the fundament of Duijnstee}

21. As Mankowski has already pointed out, the approach of relying on Duijnstee as the leading case concerning this issue has a weakness. ${ }^{32}$ The central criticism is that Duijnstee is mainly relying on the Jenard Report. ${ }^{33}$ This report states that all proceedings which are not concerned with the validity of patents, especially patent infringement cases, are governed by the general provisions of the 1968 Brussels Convention and not by its specific provisions on exclusive jurisdiction. ${ }^{34}$ Thus, the courts of the defendant's domicile would have jurisdiction according to Art. 2 of the 1968 Brussels Convention which is identical to Art. 2 of Regulation 44/2001.

22. However, a universal reading of the statement of the Jenard Report appears problematic these days. ${ }^{35}$ Since the Brussels I recast Regulation came into force, its Art. 24(4) subsection 1 gives jurisdiction to member state courts where a trade mark was registered or deposited for all proceedings concerned not only with the validity of such rights, but also with their registration. This provision is therefore wider. Since GAT, proceedings in which the plea of invalidity is raised are also governed by the specific jurisdiction according to Art. 16(4) of the 1968 Brussels Convention and consequently according to Art. 22(4) Brussels I. ${ }^{36}$ Thus, a simple reference to Duijnstee of 1983 based on an argument taken from the Jenard Report is an important historic argument, but not by itself conclusive.

23. Further, Mankowski points out that Duijnstee simply asserts that there is no reason for proceedings, which do not affect the deposition or registration itself, but are rather concerned with the legal relationship between the parties, to be referred to member state courts where such IP rights were applied for or granted. ${ }^{37}$ This is indeed not an argument but an assertion. ${ }^{38}$ Therefore, this statement alone cannot be convincing as to the limited scope of Art. 16 of the 1968 Brussels Convention or equally Art. 24(4) of the recast Brussels I Regulation.

24. On the contrary, Duijnstee applies Art. 16 of the 1968 Brussels Convention in cases where the priority of an IP right's registration is in doubt..$^{39}$ This, however, is inconsequent, as Mankowski also points out. ${ }^{40}$ Thus the question arises of how the specific provision of Art. 16 of 1968 Brussels Convention

${ }^{29}$ P. Mankowski, „Orthodoxes und Häretisches zum Umfang der ausschließlichen Zuständigkeiten aus Art. 24 Nr. 4 und Nr. 3 EuGVVO bei registrierten IP-Rechten mit Blick auf Prätendentenstreitigkeiten“, Praxis des Internationalen Privat- und Verfahrensrechts (IPRax) 2018, pp. 355, 356.

${ }^{30}$ KINDLER, GRUR 2018, pp. 1107, 1113.

${ }^{31}$ See for example M. TAXHet in F. Albrecht et al. (eds.), Beck'scher Online-Kommentar Markenrecht, $15^{\text {th }}$ ed., München, C.H. Beck, 2018, §30 MarkenG, para. 177.1.

${ }^{32}$ Mankowski, IPRax 2018, pp. 355, 356.

${ }_{33}$ Mankowski, IPRax 2018, pp. 355, 356.

${ }^{34}$ Report on the Convention on jurisdiction and enforcement of judgements in civil and commercial matters, by P. JENARD, Official Journal of the European Communities, No C 59/1-65, p. 36.

${ }^{35}$ Mankowski, IPRax 2018, pp. 355, 356.

${ }^{36}$ KINDLER, GRUR 2018, pp. 1107, 1114; MANKOWSKI, IPRax 2018, pp. 355, 356.

${ }^{37}$ ECJ, 15 November 1983, Duijnstee, C-288/82, ECLI:EU:C:1983:326, para. 26.

${ }^{38}$ See also Mankowski, IPRax 2018, pp. 355, 356.

${ }^{39}$ ECJ, 15 November 1983, Duijnstee, C-288/82, ECLI:EU:C:1983:326, para. 24.

${ }^{40}$ Mankowski, IPRax 2018, pp. 355, 356. 
cannot be governing proceedings concerned with the ownership of an IP right because they deal with the legal relationship between the parties and at the same time determine jurisdiction for questions of priority, which are in fact also a substantive legal matter concerning the relationship between the parties. ${ }^{41}$ These inconsistencies and the development in the law since 1983 make it difficult to rely heavily on Duijnstee when determining the reasoning underlying the limited scope of Art. 24(4) Brussels I Recast.

25. Nonetheless, it has been clear since Duijnstee that the vast majority of scholars support the CJEU's narrow interpretation of Art. 16 Brussels Convention and, following, of Art. 22(4) Brussels I and Art. 24(4) Brussels I Recast. ${ }^{42}$ Proceedings concerning the ownership are not included in these specific provisions and thus guided by the general provision of Art. 2(1) of the Brussels I Regulation (44/2001) as well as by Art. 4(1) Brussels I Recast.

\section{Consideration of Art. 24(3) Brussels I Recast}

26. Apart from this general acceptance, Mankowski considers it worth looking at Art. 24(3) of the Brussels I Recast Regulation as a way to give jurisdiction to member state courts where a trade mark's registration was applied for or granted ${ }^{43}$ However, since this approach has not yet been discussed by the CJEU, this case note will not analyze Art. 24(3) Brussels I recast Regulation as a possible alternative basis for exclusive jurisdiction. Only an overview over the main points shall be given here.

27. Mankowski first argues that validity in Art. 24(3) and Art. 24(4) Brussels I Recast refers to different aspects. ${ }^{44}$ While No. 3 deals with the validity of a registration as such, No. 4 deals with the validity of specific IP rights, which is not dependent on the ownership of those rights. Therefore, at least from its wording, Art. 24(3) Brussels I Recast might cover proceedings, which deal with questions of ownership. ${ }^{45}$ Nonetheless, Mankowski makes clear that this provision can only apply when the registration as such is at dispute and not the circumstances leading to it. ${ }^{46}$

28. Further, Mankowski does not regard Art. 24(4) Brussels I Recast as lex specialis. His main argument is the open wording of Art. 24(3) and (4), which neither stipulates nor excludes any hierarchy between the two subsections. ${ }^{47}$ In addition, Art. 31(1) Brussels I Recast (as the successor of Art. 29 Brussels I) states a general competitive relationship between several exclusive jurisdictions, which might also apply to the different numbers of Art. 24 Brussels I Recast. ${ }^{48}$

29. Finally, Mankowski points out that the effet utile of Art. 24(3) Brussels I Recast requires an application on disputes between parties about who is rightly registered ${ }^{49}$ consequently, Mankowski considers it most appropriate to apply Art. 24(3) Brussels I recast Regulation. ${ }^{50}$

\section{Conclusions}

30. The CJEU has once more given a narrow interpretation to Art. 22(4) Brussels I and pointed out that it does not apply to proceedings concerned with substantive issues such as the question of a trade mark's ownership. By reaffirming this position, the CJEU's decision contributes to legal certainty and should therefore be appreciated as a contribution to, and continuation, of existing case law.

\footnotetext{
${ }^{41}$ MankowsKi, IPRax 2018, pp. 355, 356.

${ }^{42}$ MankowsKi, IPRax 2018, pp. 355, 356 with further references in footnote 16; KINDLER, GRUR 2018, pp. 1107, 1114.

${ }^{43}$ Mankowski, IPRax 2018, pp. 355, 357-359.

${ }^{44}$ Mankowski, IPRax 2018, pp. 355, 358.

${ }^{45}$ Mankowski, IPRax 2018, pp. 355, 358.

${ }_{46}$ Mankowski, IPRax 2018, pp. 355, 358.

${ }^{47}$ Mankowski, IPRax 2018, pp. 355, 358.

${ }^{48}$ Mankowski, IPRax 2018, pp. 355, 358.

${ }_{49}$ MankowsKi, IPRax 2018, pp. 355, 359.

${ }^{50}$ Mankowski, IPRax 2018, pp. 355, 360.
} 
31. At the same time, it changes little in the European framework of jurisdiction in civil and commercial matters. The general rule that exceptions, which give exclusive jurisdiction to certain member state courts, are to be interpreted narrowly is emphasized since such provisions deprive the parties of all other grounds of jurisdiction.

32. Nonetheless, scholars and courts should take a closer and more critical look at the reasoning derived from the decision in Duijnstee. It is worth inquiring if this case from 1983 can still be cited unconditionally as a reference for cases concerning the new Art. 24(4) Brussels I Recast. When doing this, new alternatives such as Art. 24(3) Brussels I Recast might come into play. 